\title{
NOTE
}

\section{Novel ballast water heating technique offers cost-effective treatment to reduce the risk of global transport of harmful marine organisms}

\author{
G. R. Rigby ${ }^{1, *}$, G. M. Hallegraeff ${ }^{2}$, C. Sutton ${ }^{3}$ \\ ${ }^{1}$ Reninna Consulting, 36 Creswell Avenue, Charlestown, New South Wales 2290, Australia \\ ${ }^{2}$ School of Plant Science, University of Tasmania, GPO Box 252-55, Hobart, Tasmania 7001, Australia \\ ${ }^{3}$ CSIRO Centre for Research on Introduced Marine Pests, GPO Box 1538, Hobart, Tasmania 7001, Australia
}

\begin{abstract}
Ten billion tonnes of shipping ballast water are carried around the world annually. This provides an inadvertant mechanism for the transfer and dispersal of harmful bacteria, toxic dinoflagellates, seaweeds, molluscs, starfish, crabs and fish (Rigby \& Hallegraeff 1996). Establishment of nonindigenous and harmful organisms have resulted in signifi. cant ecological and environmental damage and also pose a threat to human health through Paralytic Shellfish Poisoning, and possibly even Cholera outbreaks (McCarthy \& Khambaty 1994). As a result of these concerns, the International Maritime Organisation has recognised shipping ballast water as an international pollutant of major consequence and is currently developing a set of draft regulations for potential use in future international shipping operations. These guidelines will require ships to undertake appropriate management or treatment operations to minimise the risks of ballast water introductions. Ballast water exchange at sea in organismdepleted deep ocean waters is currently the recommended treatment option, although this technique has some limitations (Rigby \& Hallegraeff 1994). Here we show how a novel, cost-effective heating technique using waste heat from the ship's main engine can be used to kill many unwanted organisms. Heated water flushed through 1 of the ballast tanks in an ocean trial resulted in destruction of all the zooplankton with very limited survival of the original phytoplankton. The original organisms were essentially reduced to flocculent amorphous detritus.
\end{abstract}

KEY WORDS: Shipping ballast water - Ballast water treatment Ballast water management - Ballast water heating Global transport of marine organisms

Ballast water is essential in maintaining the safety and stability of ships at sea. Discharges continue to increase in major ports throughout the world with the

•E-mail: rigby@mail.com use of larger ships and shorter transit times. The possible link between ballast water and dispersal of marine organisms was first suggested by Ostenfeld in 1908 and Peters in 1933. However, interest in ballast water as a global environmental problem has gained considerable impetus in recent years with the documented establishment of a number of nonindigenous harmful organisms around the world. Probably the most publicised ballast water introduction is the zebra mussel Dreissena polymorpha in North America. First discovered in Lake St. Claire in 1988, it has since become established in more than $50 \%$ of the waterways in the USA and it has been estimated that it will cost US $\$ 5$ billion up to the turn of the century to control (Edwards 1994). The toxic dinoflagellate Gymnodinium catenatum, linked strongly to ballast water discharges, first established in the Derwent and Huon estuaries of Tasmania in 1972 and coincident with the establishment of a new woodchip mill, has been responsible for the regular closure of shellfish harvesting as a result of high Paralytic Shellfish Poisoning toxin levels (Hallegraeff \& Bolch 1992, McMinn et al. 1997). Ballast water has been suggested as the vector for the introduction of the American Atlantic comb jelly Mnemiopsis leidyi in the Black Sea (Vinogradov et al. 1989). Recent studies have also suggested that Cholera introduced through ballast water could present a health problem in some areas (Mc Carthy \& Khambaty 1994). Carlton et al. 1995 have estimated that more than 3000 species are transported by ships each day, and some 40 recent invasions have been mediated by ballast water (Carlton \& Geller 1993). 
In response to these biological invasions, International Maritime Organisation (IMO) concerns and the introduction of ballast water guidelines and regulations in various parts of the world, research and development programs have been initiated in Australia, New Zealand, USA, Germany, Canada, Japan, Israel, Ireland, Wales, Sweden and Norway to identify some of the key issues involved and to develop effective management and treatment options to minimise the risks of future introductions (ICES 1997). A range of physical and chemical treatment options (such as chlorine or hydrogen peroxide treatment, ozonation, ultraviolet radiation, electric shock, filtration) have been suggested to kill unwanted organisms, however, the majority of these have been shown to be ineffective, unsafe, too costly or environmentally unattractive for long-term universal use (Rigby \& Hallegraeff 1994, Hallegraeff 1998). Exchange of ballast water (either by continually flushing tanks or emptying and refilling) in the open ocean or in a designated 'safe' area is currently the only option available to shippers.

We have developed an alternative option which utilises waste heat from the ship's main engine to heat the ballast water to a temperature of 37 to $38^{\circ} \mathrm{C}$, sufficient to kill many unwanted organisms. Toxic dinoflagellates were used as a model organism, since they are probably the best studied target species to assess the bioeconomic risks of ballast water introductions into Australian waters (Rigby et al. 1993). Toxic dinoflagellates and their cysts are very resistant to various treatments, and therefore, if successful with dinoflagellates, the treatment is likely to be effective for a significant number of other unwanted organisms such as seaweeds, crabs, worms, fish, starfish, fanworms, etc.

The potential for inactivating toxic dinoflagellate cysts and killing other marine organisms in ships' ballast water by heating has attracted recent interest as an environmentally responsible, and potentially cost-effective treatment option for minimising the risks associated with the international translocation and subsequent establishment of these organisms (Bolch \& Hallegraeff 1993, Rigby \& Hallegraeff 1994). Initial laboratory work (Bolch \& Hallegraeff 1993) indicated that heating Gymnodinium catenatum dinoflagellate cysts to temperatures of 40 to $45^{\circ} \mathrm{C}$ for very short periods of time $(90$ to $30 \mathrm{~s}$ ) resulted in death. Lower temperatures at these short treatment times were less effective in killing the organisms.

Waste heat from a ship's main engine, which is currently pumped overboard as a waste product, can potentially provide a cost-effective source of heat. However, if this option is to be used, heating needs to take place during transit, as the ship's engine is not usually in operation during ballasting or deballasting. An analysis of available heat on the Broken Hill Propri- etary Company Limited (BHP)-owned $141475 \mathrm{dwt}$ (deadweight tonnes) bulk carrier, 'Iron Whyalla', indicated that the most appropriate means of utilising this heat would be to flush the rejected hot ocean water used to cool the freshwater engine cooling water (available at a temperature of around $42^{\circ} \mathrm{C}$, and usually discharged into the ocean) through the ballast water tanks in sequence, allowing the excess water to overflow from the ballast tanks (Fig. 1, Rigby \& Taylor 1993). In addition to heating the ballast water, the flushing effect of the hot water will also significantly reduce the amount of originally ballasted water (and organisms) present at the end of the heating/flushing period.

A preliminary biological examination of this oceanic water heated by the engine's cooling system on a voyage on the 'Iron Whyalla' (Rigby \& Hallegraeff 1993) showed that no phytoplankton or zooplankton survived, suggesting that treatment in this manner had potential. However, without significant modification to the main ship's engine and waste heat recovery systems, there is insufficient heat available to reach a uniform ballast water temperature of $40^{\circ} \mathrm{C}$ in all tanks. Temperatures in the vicinity of 35 to $38^{\circ} \mathrm{C}$ are likely to be possible (after 24 to $30 \mathrm{~h}$ flushing of each tank) on a voyage from Japan to Australia.

On the basis of this data, a series of further experimental tests (Hallegraeff et al. 1997) demontrated that most phytoplankton algae tested, including the diatom Skeletonema costatum, dinoflagellates Amphidinium carterae, Gymnodinium catenatum and Alexandrium catenella, and the golden brown flagellate Heterosigma akashiwo in the vegetative stage, could be readily killed at temperatures as low as $35^{\circ} \mathrm{C}$ and treatment times in the range of $30 \mathrm{~min}$ to several hours. In addition, significant mortality was also achieved with $G$. catenatum and A. catenella cysts using longer incubation times (several hours) at temperatures as low as 35 to $37.5^{\circ} \mathrm{C}$, with total mortality achieved at $38^{\circ} \mathrm{C}$ after $4.5 \mathrm{~h}$.

In order to test the practicality and effectiveness of this treatment option, a shipboard trial on the 'Iron Whyalla' was undertaken to confirm earlier heating predictions, assess the behaviour of the phytoplankton

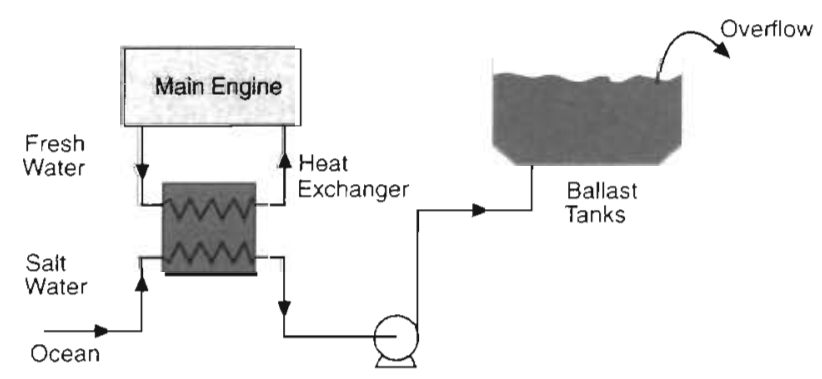

Fig. 1. Heating circuit used to simultaneously flush and heat ballast water on the 'Iron Whyalla' 
and zooplankton present during the heating process and to assess the suitability of this option for future ballast water control. This trial took place in April 1997 during a 10 d voyage from Port Kembla in New South Wales to Port Hedland in Western Australia.

Some additional ballast water piping and flowmeasuring equipment was installed in the ship during dry docking to allow the heated water to be diverted via the Fire and General Services pump into either the port or starboard tanks. The excess water was allowed to overflow onto the deck through the breather pipes. No. 2 ballast water tanks were chosen as the test tanks. The portside set of tanks (topside, trunk and double bottom containing 6350 tonnes of water) were used for testing purposes, and the starboard set as the control tanks. A series of $50 \mathrm{~mm}$ sampling pipes and thermocouples were fitted to the tanks to allow sampling and monitoring of temperatures. Net samples were also taken from the port and tanks at various times during ballasting and throughout the voyage.

Following ballasting in Port Kembla, the heating trial was initiated in the Arafura Sea at a starting ocean temperature of $28.5^{\circ} \mathrm{C}$ and completed within the tropical waters over a $30 \mathrm{~h}$ period (Fig, 2). After approximately 1 tank volume of water had been flushed through the tank (12 h), the aft overflow temperature had reached $35.4^{\circ} \mathrm{C}$. This temperature reached $36.9^{\circ} \mathrm{C}$ after 2 tank flushing volumes. At the end of the flushing period (2.5 tank volumes), this temperature had reached $38.4^{\circ} \mathrm{C}$. At the end of the trial, all of the water in the tank had reached a temperature of at least $37^{\circ} \mathrm{C}$, and after $30 \mathrm{~h}$ from commencement of flushing, had exceeded $38^{\circ} \mathrm{C}$. The water in the heated tank retained its temperature for some time, and $20 \mathrm{~h}$ later was still in excess of $35^{\circ} \mathrm{C}$, and $40 \mathrm{~h}$ later in excess of $33.5^{\circ} \mathrm{C}$. The water temperatures in the control tank were essentially uniform (within $2^{\circ} \mathrm{C}$ ) throughout the heating trial and increased by approximately $1{ }^{\circ} \mathrm{C}$ over the period that the heating trial progressed (as a result of the higher ocean temperature).

On board microscopic observation of heated water samples (Rigby et al. 1998) showed that none of the zooplankton (mainly chaetognaths and copepods) and only very limited original phytoplankton (mainly dinoflagellates) survived the heat treatment (Fig. 3). The original organisms were reduced to flocculent amorphous detritus. Subsequent culturing efforts on the heated ballast tank samples only produced growth of some small $(5 \mu \mathrm{m})$ diatoms and colourless ciliates which are considered to be of little consequence. Although no toxic dinoflagellate cysts were present in the tanks, based on earlier laboratory experiments, it is probable that these would have been effectively killed by the temperatures achieved during the heating trial, since essentially all of the water reached 37 to $38^{\circ} \mathrm{C}$.

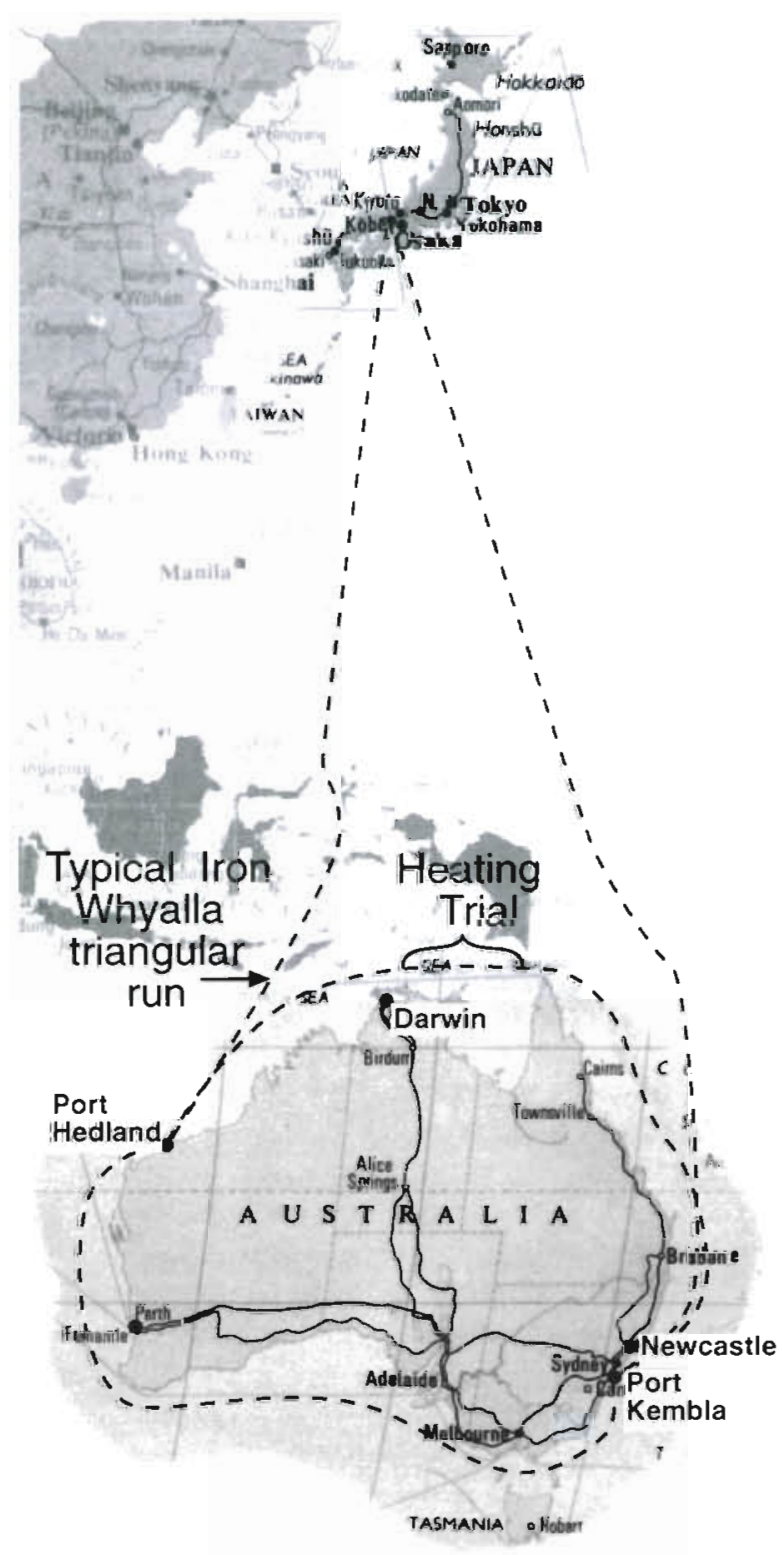

Fig. 2. Typical triangular route for the 'Iron Whyalla' involving transport of iron ore from Port Hedland in Western Australia to Port Kembla and/or Newcastle in New South Wales, and coal from Newcastle to Japan. Ballast water is typically taken on in Port Kembla, Newcastle and Japan as the iron ore and coal are unloaded. It is discharged in Newcastle and Port Hedland as iron ore and coal are loaded. The route of the trial voyage and location of the heating trial in the Arafura Sea is indicated

On board microscopic observations of survival of some plankton organisms from tropical waters when passed through the engine cooling water heat exchangers suggest that short term heating ( 1 to $2 \mathrm{~min}$ at 38.5 to $41.5^{\circ} \mathrm{C}$ ) may be an insufficient treatment option. The present results suggest that heating of the entire tank for prolonged periods of time is more effective at killing plankton than short-term acute exposure. 


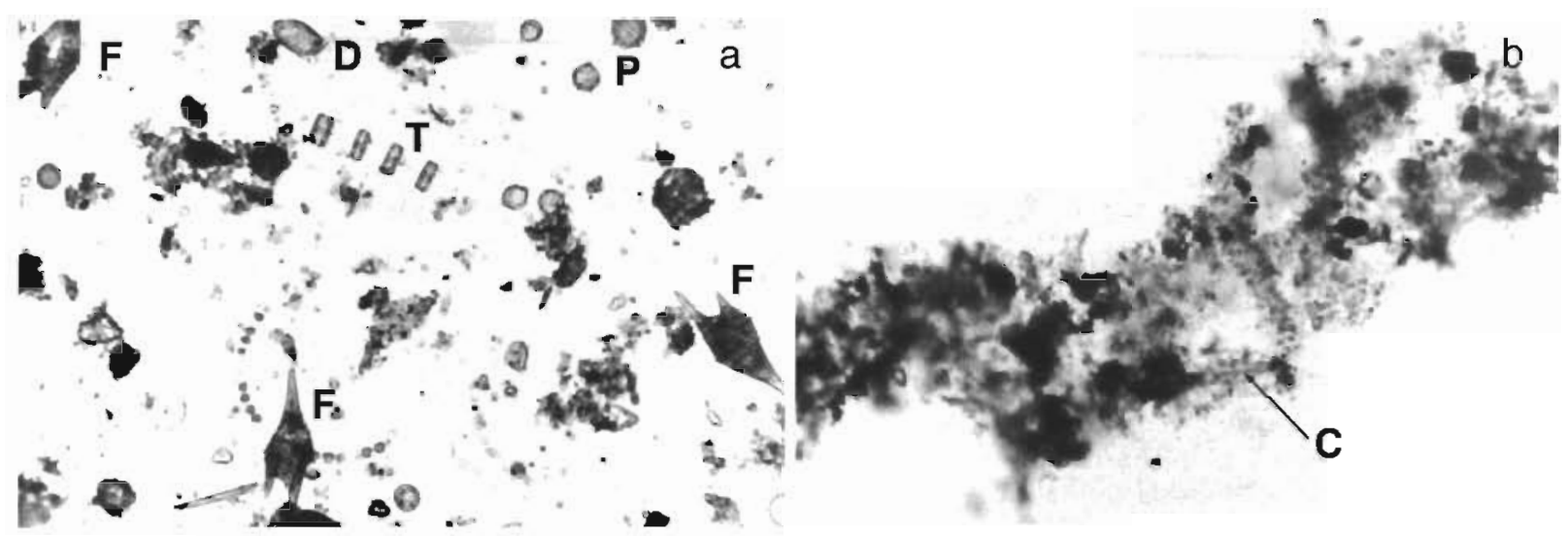

Fig. 3. (a) Port Kembla phytoplankton taken into No. 2 portside tank, dominated by the dinoflagellates Ceratium furca (F), Dinophysis acuminata and Dinophysis rotundata (D), Protoperidinium pellucidum (P), and the diatom Thalassiosira rotula (T) (b) Flocculent amorphous detritus remaining in the ballast tank at the end of the heating/flushing trial, including broken diatom frustules and empty copepod carapaces (C)

This approach to ballast water management is environmentally very attractive since it does not necessitate the use of chemicals or biocides that could themselves be harmful to the environment. The technique is safe since the tanks are always full of water (as opposed to some ocean exchange options where tanks are pumped empty at sea and then refilled creating potentially dangerous stresses and bending moments), cost-effective since it makes use of waste heat normally discarded (cost estimated to be approximately US 3.0 cents per tonne ballast water, excluding any costs for installation of additional pipework or equipment, Rigby \& Taylor 1999), and is likely to be practical for use by a wide range of ships. In addition to the effects of heating, this approach has the added benefit of removing a substantial amount $(>90 \%)$ of the original plankton by the flushing action of the hot water.

If this heating option were to be adopted on the 'Iron Whyalla', or any other ship on a routine basis, it would be necessary to make adequate provisions to ensure that appropriate pipework and overflow arrangements were designed, approved by the appropriate classification authorities, and installed in such a way that safe operation could be ensured. Installation of appropriate pipework and other associated equipment in a new ship to optimise the effectiveness of heat treatment would not result in any significant cost penalty or impediment to safe ship operation.

This trial demonstrated that this method would be effective in heating all the ballast water on the 'Iron Whyalla' to temperatures of $38^{\circ} \mathrm{C}$ for extended periods during a typical return voyage from Japan to Australia, or on voyages of similar lengths. This type of ballast water management would be less appropriate for bulk carriers on Australian domestic coastal trips or on international routes involving short voyage times, as there would be insufficient time to complete the heating operation in all tanks. Similarly, ballast water heat treatment may be less effective for ships traversing areas where ocean temperatures are very low $(<15$ to $20^{\circ} \mathrm{C}$ ), as this could increase the heating time or reduce the final temperature. An initial evaluation of the possible effects of elevated temperatures on ballast tank corrosion has indicated that this effect is not likely to present a major concern. Concerns that such mild heating of ballast water could stimulate the growth of pathogenic bacteria such as Vibrio cholerae have not been substantiated by simulated laboratory culture experiments (Desmarchelier \& Wong 1998).

The magnitude of and potential dire ecological implications resulting from the global problem of translocation of nonindigenous marine pests deserve the urgent and ongoing attention of both environmental policy makers and the shipping industry. We hope that the suggestions proposed here can contribute towards finding an effective, safe, economically viable, and above all environmentally friendly solution to the global ballast water problem.

Acknowledgements. This work was undertaken as part of the Australian Quarantine and Inspection Service Strategic Ballast Water Research Program funded by the Australian Government and the Australian Shipping Industry, and this support is acknowledged. We would also like to thank Alan Taylor and other BHP Transport and BHP Research Officers for their assistance in making preparations and assisting with the shipboard trials.

\section{LITERATURE CITED}

Bolch CJ, Hallegraeff GM (1993) Chemical and physical treatment options to kill toxic dinoflagellate cysts in ships' ballast water. J Mar Environ Eng 1:23-29 
Carlton JT, Geller JB (1993) Ecological roulette: the global transport of non-indigenous marine organisms. Science 261(5117):78-82

Carlton JT, Reid DM, van Leeuwen H (1995) The role of shipping in the introduction of non indigenous aquatic organisms to the coastal waters of the United States (other than the Great Lakes) and an analysis of control options. National Sea Grant College Programme/CT Sea Grant Project R/ES6

Desmarchelier P, Wong F (1998) The potential for Vibrio cholerae to translocate and establish in Australian waters. AQIS Ballast Water Research Series, Report No. 10, Australian Government Publishing Service, Canberra

Edwards G (1994) US response to aquatic nuisance species. Proceedings of the conference and workshop on nonindigenous estuarine and marine organisms. US Dept. Commerce, National Oceanic and Atmospheric Administration $1-3$

Hallegraeff GM, Bolch CJ (1992) Transport of dinoflagellate cysts in ship's ballast water: implications for plankton biogeography and aquaculture. J Plankton Res 14: $1067-1084$

Hallegraeff GM, Valentine JP, Marshall JA, Bolch CJ (1997) Temperature tolerances of toxic dinoflagellate cysts: application to the treatment of ships' ballast water. Aquat Ecol 31:47-52

Hallegraeff GM (1998) Transport of toxic dinoflagellates via ships' ballast water: bioeconomic risk assessment and efficacy of possible ballast water management strategies. Mar Ecol Prog Ser 168:297-309

International Council for the Exploration of the Sea (ICES) (1997) Report of the ICES/IOC/IMO study group on ballast water and sediments, La Tremblade, France April

McCarthy SA, Khambaty FM (1994) International dissemination of epidemic Vibrio Cholerae by cargo ship ballast water and other nonpotable waters. Appl Environ Microbiol 60:2597-2601

Mc Minn A, Hallegraeff GM, Thomson P, Jenkinson AV, Heijnis $H$ (1997) Cyst and radionucleotide evidence for the introduction of the toxic dinoflagellate Gymnodinium catenatum into Tasmanian waters. Mar Ecol Prog Ser 161: $165-172$

Ostenfeld CH (1908) On the immigration of Biddulphia sinensis Grev, and its occurrence in the North Sea during

Editorial responsibility: Otto Kinne (Editor),

Oldendorf/Luhe, Germany
1903-1907. Medd Dan Fisk-Havunders Serie Plankton. $1(6): 1-44$

Peters N (1933) Die Chinesische Wollhand Krabbe (Eriocheir sinensis H. Milne-Edwards) in Deutschland. Zool Anz 104: $59-156$

Rigby GR, Steverson IG, Bolch CJ, Hallegraeff GM (1993) The transfer and treatment of shipping ballast water to reduce the dispersal of toxic marine dinoflagellates. In: Smayda TJ, Shimzu Y (eds) Toxic phytoplankton blooms in the sea. Elsevier, Amsterdam, p 169-176

Rigby GR, Taylor AH (1993) Shipping ballast water - heating as a means of destroying potentially harmful marine organisms. BHP Research Tech. Note BHPR/ENV/TN/93/005

Rigby GR, Hallegraeff GM (1993) Ballast water exchange trial and behaviour of marine plankton on the M.V. 'Iron Whyalla', in Japan and en-route to Canada. In: AQIS Ballast Water Research Series, Report No. 2. Sept. Australian Government Publishing Service, Canberra

Rigby GR, Hallegraeff GM (1994) The transfer and control of harmful marine organisms in shipping ballast water. behaviour of marine plankton and ballast water exchange trials on the M.V. 'Iron Whyalla'. J Mar Environ Eng 1: $9-10$

Rigby GR, Hallegraeff GM (1996) Ballast water controls to minimise the translocation and establishment of toxic marine phytoplankton - what progress have we made and where are we going? In: Yasumoto $T$, Oshima $Y$, Fukuyo $Y$ (eds) Harmful and toxic algal blooms. International Oceanographic Commission of UNESCO, Paris, p 201-204

Rigby GR, Taylor AH (1999) Progress in the management and treatment of shipping ballast water to minimise the risks of translocating harmful nonindigenous aquatic organisms. Proc National Conference on Marine Bioinvasions, MIT, Cambridge, MA, USA, 25-27 Jan

Rigby GR, Hallegraeff GM, Sutton C (1998) Ballast water heating and sampling trials on the BHP ship MV 'Iron Whyalla' in Port Kembla and en-route to Port Hedland. AQIS Ballast Water Research Series, Report No. 11. Oct. Australian Government Publishing Service, Canberra

Vinogradov ME, Shushkina EA, Musayera EI, Sorokin PY (1989) A newly acclimated species in the Black Sea: the ctenophore Mnemiopsis leidyi (Ctenophora: Lobata). Okeanologiya 29(2):220-224

Submitted: June 21, 1999; Accepted: September 9, 1999 Proots received from author(s): December 22, 1999 